\title{
Screening of $\alpha$-Tocopherol Transfer Protein Sensitive Genes in Human Hepatoma Cells (HepG2)
}

\author{
Yang-Hua $\mathrm{Qu}^{\dagger}{ }^{\dagger}$ Jun-Cai Fu ${ }^{\dagger}$, Kun Liu, Zhao-Yun Zuo, Hui-Na Jia, Yong Ma and Hai-Ling Luo * \\ State Key Laboratory of Animal Nutrition, College of Animal Science and Technology, \\ China Agricultural University, Beijing 100193, China; quyanghua@cau.edu.cn (Y.-H.Q.); \\ juncaifu@cau.edu.cn (J.-C.F.); liukun_139@163.com (K.L.); tianai305@163.com (Z.-Y.Z.); \\ jiahuina19880505@126.com (H.-N.J.); syau2010@126.com (Y.M.) \\ * Correspondence: luohailing@cau.edu.cn; Tel.: +86-10-6273-4597 \\ + The authors contributed equally to the work.
}

Academic Editor: Johannes Haybaeck

Received: 15 May 2016; Accepted: 21 June 2016; Published: 27 June 2016

\begin{abstract}
Tocopherol transfer protein $(\alpha$-TTP) is a $\sim 32 \mathrm{kDa}$ protein expressed mainly in hepatocytes. The major function of the protein is to bind specifically to $\alpha$-tocopherol and, together, the complex transfers from late lysosomes to the cell membrane. A previous study indicated that some factors might be required in the transferring process. However, there is little information available about the potential transferring factors. In addition, there remains much to learn about other physiological processes which $\alpha$-TTP might participate in. Thus, in this study a human $\alpha$-TTP eukaryotic expression vector was successfully constructed and expressed in human hepatoma cells (HepG2). The sensitive genes related to $\alpha$-TTP were then screened by microarray technology. Results showed that expression of the vector in HepG2 cells led to the identification of 323 genes showing differential expression. The differentially expressed transcripts were divided into four main categories, including (1) cell inflammation; (2) cell cycle and cell apoptosis; (3) cell signaling and gene regulation; and (4) cellular movement. A few cellular movement related transcripts were selected and verified by quantitative real-time PCR. Expressions of some were significantly increased in $\alpha$-TTP-expressed group, which indicated that these factors were likely to play a role in the transferring process.
\end{abstract}

Keywords: $\alpha$-tocopherol transfer protein; vitamin E; sensitive genes; microarray

\section{Introduction}

Vitamin E was first discovered as a factor crucial for the reproduction of rats; later it was generally considered as an essential lipid-soluble antioxidant [1,2]. Eight different forms of vitamin E exist in nature: $\alpha-, \beta-, \gamma-, \delta$-tocopherols with a saturated phytyl side chain, and $\alpha-, \beta-, \gamma-, \delta$-tocotrienols with an unsaturated isoprenoid side chain. It is generally accepted that $\alpha$-tocopherol has the highest biological activity in every variety of form [3]. As a potent antioxidant, vitamin E can prevent lipid peroxidation by scavenging reactive oxygen and nitrogen species [4]. In addition to its antioxidant function, further research suggested that vitamin E played a pivotal role in modulating enzyme activity, cell multiplication, inflammatory response, signal transduction and gene expression $[5,6]$.

Recently, numerous studies have focused on the intracellular transport of vitamin E. In the small intestine, dietary vitamin $\mathrm{E}$ is absorbed from epithelial cells and delivered to the liver with chylomicrons [7]. In hepatocytes, the $\alpha$-tocopherol transfer protein $(\alpha$-TTP) is responsible for the transport of vitamin E. $\alpha$-TTP was first described in rat liver cytoplasm in 1975. It is known for its selective binding to $\alpha$-tocopherol over other forms of vitamin E [8]. The protein binds $\alpha$-tocopherol with high affinity and catalyzes its transfer from late lysosomes to the cell membrane [9]. It was first purified from rat liver cytoplasm, and then from human liver. Subsequently, the $\alpha$-TTP gene 
sequences from both species have also been cloned [10-12]. It has received a great deal of attention due to the fact that a mutation of the $\alpha$-TTP gene was responsible for ataxia with vitamin E deficiency (AVED), resulting, not only in serum vitamin E deficiency, but neurodegeneration as well [13]. Mice carrying a mutated $\alpha$-TTP gene exhibited symptoms similar to humans with AVED, which even led to infertility [14]. These findings indicated that $\alpha$-TTP played a key role in transferring $\alpha$-tocopherol and maintaining its concentration in the plasma at an elevated level.

Extensive research was conducted in rats and humans to clarify whether the level of vitamin $\mathrm{E}$ could regulate the expression of $\alpha$-TTP for decades, but the results seem to be inconclusive. Kim [15] reported that vitamin E supplementation could lower both mRNA and protein expression in rat liver compared with control group, and diets with insufficient vitamin E increased $\alpha$-TTP mRNA levels, without affecting $\alpha$-TTP protein concentrations. On the other hand, Shaw [16] suggested that the lack of vitamin E lowered the expression of the $\alpha$-TTP protein, but had no effects on $\alpha$-TTP transcripts. Fechner [17] resupplied vitamin $\mathrm{E}$ to rats that were previously fed with diets containing insufficient levels of vitamin E for five weeks; this led to an increase in $\alpha$-TTP mRNA expression. Additional studies later in rat and pig liver, resulted in similar conclusions, namely that vitamin $\mathrm{E}$ levels were unrelated to $\alpha$-TTP expression [18-20]. Apart from the experiments in liver tissue, it was also reported in human hepatoma cells by Thakur that treatment with vitamin E would bring about a time- and dose-dependent increase in $\alpha$-TTP levels [21]. However, it is still difficult to get consistent information from former outcomes.

A series of experiments were conducted in our laboratory in sheep to find out the connection between $\alpha$-TTP and vitamin E from 2008. We cloned the full-length cDNA sequence of the ovine $\alpha$-TTP gene, which was added to the Genbank database (ID: NM_001198882) in 2009, and used it to perform bioinformatic analysis. In addition, we generated a monoclonal antibody against ovine $\alpha$-TTP in 2014 . Further studies suggested that high levels of vitamin E supplementation significantly increased ovine $\alpha$-TTP protein concentrations in the liver. In tissues other than the liver, the expression of the $\alpha$-TTP gene also increased by the vitamin E supplementation [22-25]. Nevertheless, there remains much to learn about the $\alpha$-tocopherol and its transporter. A previous report indicated that some factors contributed to the transport of vitamin E by $\alpha$-TTP [26], but the information about it was grossly absent. Furthermore, whether there are other physiological processes that $\alpha$-TTP is involved in or not is poorly studied. Therefore, relevant investigation should be designed to clarify it.

The human hepatoma cell (HepG2) is a commonly used model in vitamin E and $\alpha$-TTP research, as it is unable to express $\alpha$-TTP itself in vitro. Expression of TTP in freshly prepared primary hepatocytes declines precipitously following isolation. However, one can transfect TTP gene into the cells by constructing expression vectors to study properties of the protein [9]. In order to illustrate the physiological processes, which $\alpha$-TTP participates in, and identify transport-related factors, a human $\alpha$-TTP eukaryotic expression vector was constructed and expressed in HepG2 cells in this experiment. Its sensitive genes were then identified by using microarray technology and their functions were analyzed in a comprehensive way. The results indicated that $\alpha$-TTP was involved in many different physiological processes. Moreover, a few possible transport-related genes were selected and verified by quantitative real-time PCR. It is speculated that some of them might be required in the transport process.

\section{Results}

\subsection{Expression of Human $\alpha$-Tocopherol Transfer Protein ( $\alpha$-TTP) Eukaryotic Expression Vector in Human Hepatoma Cells (HepG2)}

Quantitative real-time PCR, Western blot and immunocytochemical analysis all showed that the human $\alpha$-TTP eukaryotic expression vector was expressed in HepG2 cells with high efficiency, compared with blank control group and empty vector transfection control group (Figure 1). This indicated the successful construction of the expression vector. 
A

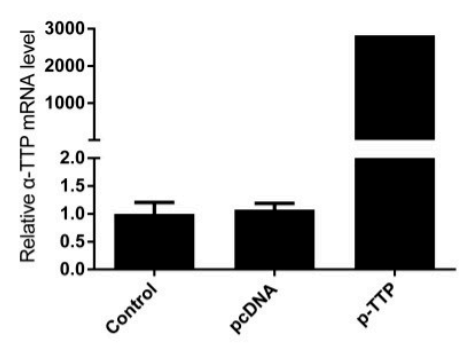

B

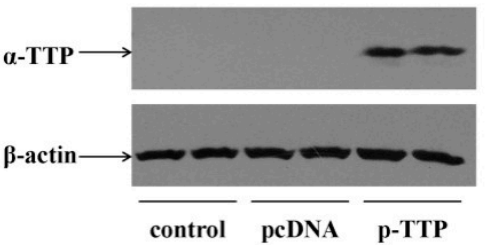

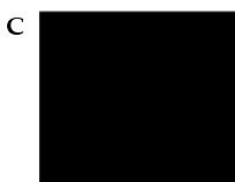

control

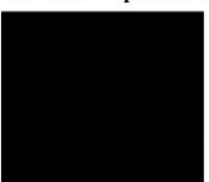

peDNA

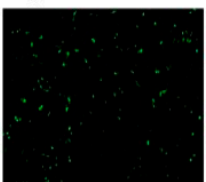

p-TTP

Figure 1. Expression of human $\alpha$-tocopherol transfer protein ( $\alpha$-TTP) eukaryotic expression vector in Human Hepatoma cells (HepG2). (A) Result of quantitative real-time PCR; (B) Result of Western blot; (C) Result of Immunofluorescence $(10 \times)$. pcDNA: pcDNA3.1-mycHisa empty vector; p-TTP: human $\alpha$-TTP eukaryotic expression vector.

\subsection{Screening Genes Related to $\alpha$-TTP}

The microarray analysis detected 323 differentially expressed genes in cells expressing the human $\alpha$-TTP eukaryotic expression vector. Of these genes, 256 were upregulated and 67 were downregulated, as compared to the empty vector group. The selected genes were classified after Gene Ontology annotation and Pathway analysis; classification of the $\alpha$-TTP related genes is shown in Table 1 .

Table 1. Classification of $\alpha$-tocopherol transfer protein ( $\alpha$-TTP)-related genes.

\begin{tabular}{|c|c|c|c|}
\hline Classification & $\begin{array}{c}\text { Genbank Accession } \\
\text { Number }\end{array}$ & Name of Gene & Fold Change \\
\hline \multirow{9}{*}{$\begin{array}{l}\text { Genes related to cell } \\
\text { inflammation }\end{array}$} & NM_004688 & N-myc (and STAT) interactor & 1.70 \\
\hline & NM_001008540 & Chemokine ( $C-X-C$ motif) receptor 4 & 1.67 \\
\hline & NM_139266 & Signal transducer and activator of transcription 1 & 1.65 \\
\hline & NM_002026 & Fibronectin 1 & 1.62 \\
\hline & NM_002310 & Leukemia inhibitory factor receptor $\alpha$ & 1.58 \\
\hline & NM_000877 & Interleukin 1 receptor & 1.51 \\
\hline & NM_001065 & Tumor necrosis factor receptor superfamily, member $1 A$ & 1.58 \\
\hline & NM_001561 & Tumor necrosis factor receptor superfamily, member 9 & -2.00 \\
\hline & NM_001190942 & Tumor necrosis factor receptor superfamily, member 10 & 3.14 \\
\hline \multirow{14}{*}{$\begin{array}{l}\text { Genes related to cell } \\
\text { cycle and cell apoptosis }\end{array}$} & NM_001030055 & Rho GTPase activating protein 5 & 1.51 \\
\hline & NM_022873 & Interferon, $\alpha$-inducible protein 6 & 2.22 \\
\hline & NM_001206701 & SP100 nuclear antigen & 1.74 \\
\hline & NM_001269 & Regulator of chromosome condensation 1 & -1.56 \\
\hline & NM_181558 & Replication factor C (activator 1 ) 3 & 1.52 \\
\hline & NM_005531 & Interferon, $\gamma$-inducible protein 16 & 1.51 \\
\hline & NM_001003943 & BCL2 modifying factor & 1.55 \\
\hline & NM_001257387 & Checkpoint kinase 2 & 1.60 \\
\hline & NM_004741 & Nucleolar and coiled-body phosphoprotein 1 & -1.54 \\
\hline & NM_001267058 & Caspase 7 , apoptosis-related cysteine peptidase & 1.52 \\
\hline & NM_001143762 & Eukaryotic translation initiation factor $5 \mathrm{~A}$ & -1.73 \\
\hline & NM_004052 & BCL2/adenovirus E1B $19 \mathrm{kDa}$ interacting protein 3 & 1.55 \\
\hline & NM_001813 & Centromere protein $E$ & 1.72 \\
\hline & NM_016343 & Centromere protein F, 350/400 ka (mitosin) & 1.54 \\
\hline
\end{tabular}


Table 1. Cont.

\begin{tabular}{cclc}
\hline Classification & $\begin{array}{c}\text { Genbank Accession } \\
\text { Number }\end{array}$ & \multicolumn{1}{c}{ Name of Gene } & Fold Change \\
\hline Genes related to cell & NM_004031 & Interferon regulatory factor 7 & 1.84 \\
signaling and gene & NM_001243084 & Hypoxia-inducible factor 1 & 1.71 \\
regulation & NM_198318 & Protein arginine methyltransferase & -1.58 \\
& NM_012099 & CD3e molecule, epsilon associated protein & -1.72 \\
\hline & NM_006364 & Sec23 homolog A & 1.51 \\
Genes involved in the & NM_022147 & Receptor transporter protein 4 & 3.13 \\
cellular movement & NM_004669 & Chloride intracellular channel 3 & 1.57 \\
& NM_001813 & Centromere protein E & 1.72 \\
& NM_000218 & Potassium voltage-gated channel subfamily Q member 1 & 1.53 \\
& NM_001172713 & Golgi autoantigen, golgin subfamily a, 4 & 1.70 \\
& NM_004052 & BCL2/adenovirus E1B 19 $k$ Da interacting protein 3
\end{tabular}

\subsection{Verification of the Transport-Related Genes}

According to previous studies, $\alpha$-tocopherol could combine with $\alpha$-TTP in lysosomes after they got into hepatocytes, then was carried to the cell membranes by $\alpha$-TTP [9]. However, the detailed process of the transfer remained unclear. One report suggested that $\alpha$-TTP may need some factors to finish the process [26]. In the present study we hypothesized that certain molecules involved in intracellular movement were likely to regulate the transfer of complexes. A few transcripts were selected after microarray analysis, including Sec23 homolog A (SEC23 A), receptor transporter protein 4 (RTP4), chloride intracellular channel 3 (CLIC3), centromere protein E (CENPE), Potassium voltage-gated channel, KQT-like subfamily (KCNQ1), golgi autoantigen, golgin subfamily a, 4 (GOLGA4), Bcl2/adenovirus E1B $19 \mathrm{kDa}$ interacting protein 3 (BNIP3) and Centormere protein F, 350/400 ka (CENPF), then qRT-PCR was applied to quantitate the expression of these genes. Most gene expression levels in qRT-PCR showed similar trend with microarray data. The result showed that expression levels of these genes related to cellular movement changed to different degrees (Figure 2). The expression of RTP4, CENPE and BNIP3 increased significantly than in the control group. The expression of golgi autoantigen, golgin subfamily a, 4 (GOLGA4) also showed more than two times increase than in the control group.

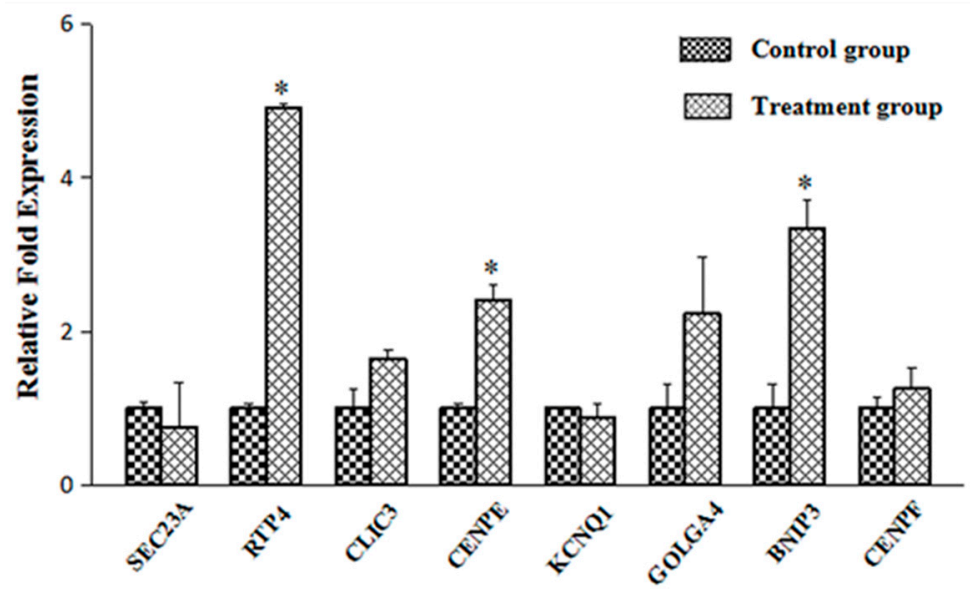

Figure 2. Expression levels of $\alpha$-TTP related genes. SEC23A: Sec23 homolog A; RTP4: receptor transporter protein 4; CLIC3: chloride intracellular channel 3; CENPE: centromere protein E; KCNQ1: potassium voltage-gated channel subfamily $\mathrm{Q}$ member 1; GOLGA4: golgi autoantigen, golgin subfamily a, 4; BNIP3: BCL2/adenovirus E1B $19 \mathrm{kDa}$ interacting protein 3; CENPF: centromere protein F. Data are presented as mean \pm standard error; the asterisk indicated significant difference between control and treatment group. 


\section{Discussion}

Recently, $\alpha$-TTP received extensive attention due to its irreplaceable function in transferring $\alpha$-tocopherol in hepatocytes. In order to obtain more information about its physiological function and interaction mechanisms with vitamin $\mathrm{E}$, it is necessary to investigate genes that are sensitive to changes in its intracellular concentration. HepG2 cell is a well-known cell line that has no ability to express $\alpha$-TTP in vitro [9]. In this study, we transfected TTP gene into HepG2 cells by constructing human $\alpha$-TTP eukaryotic expression vector. Quantitative real-time PCR, Western blot and immunocytochemical analysis were all used to detect the expression. Compared with blank control group and empty vector transfection group, which did not express $\alpha$-TTP on account of the character of HepG2 cells, the efficient expression in human $\alpha$-TTP eukaryotic expression vector group indicated the successful construction of this vector, which established the foundation for further research. RNA from HepG2 cells in control group and treatment group was then extracted combined with subsequent microarray analysis. A total of 323 differentially expressed genes (more than 1.5-fold) were identified, including 256 up-regulated and 67 down-regulated ones. After GO annotation and Pathway analysis, these differentially expressed transcripts were divided into four main categories, such as (1) cell inflammation; (2) cell cycle and apoptosis; (3) cell signaling and gene regulation; (4) cellular movement.

It was noted that the inflammatory-response system contained a wide spectrum of mediators. According to one report, $\alpha$-TTP null mice showed enhanced inflammatory responses, probably as a result of plasma and tissue $\alpha$-tocopherol deficiency [27]. Another study, using gene expression profiling revealed that a cluster of genes related to inflammation was regulated in the heart tissue of $\alpha$-TTP null mice. Such genes included immunoglobulin kappa chain and heavy chain, tumor necrosis factor receptor superfamily, chemikine ( $\mathrm{C}-\mathrm{C}$ motif) receptor, chemokine ( $\mathrm{C}-\mathrm{X}-\mathrm{C}$ motif) ligand and interleukin-1 receptor-associated kinase 1 , suggesting increased inflammatory response in $\alpha$-TTP ${ }^{-/}$cardiac tissue on account of lacking $\alpha$-tocopherol [28]. Present results are compatible with these studies. Three members of the tumor necrosis factor receptor superfamily, well known as a critical factor in eliciting rapid inflammatory events [29], were induced by $\alpha$-TTP. Chemokine (C-X-C motif) receptor 4 , which was upregulated by 1.67 -fold, could reduce bronchial inflammation [30]. Interleukin 1 receptor was another gene related to $\alpha$-TTP that showed a 1.51-fold upregulation. In addition, some related genes, including signal transducer and activator of transcription I, $\mathrm{N}$-myc interactor, fibronectin and Leukemia inhibitory factor receptor were also upregulated by $1.65-, 1.70-, 1.62-$ and 1.58 -fold, respectively. These factors mostly participate in different cell inflammatory-response mechanisms [31,32], indicating that $\alpha$-TTP might also be involved in these processes. Considering the differences in the experimental materials, the results might be better explained by assuming a direct effect of $\alpha$-TTP on the inflammation-related genes, instead of simply lowering $\alpha$-tocopherol concentration.

In the present study, we found an indication for altered transcripts related to cell cycle and apoptosis. For example, we detected a 1.56-fold decrease in the mRNA for the regulator of chromosome condensation 1 and a 1.60-fold increase in the mRNA for the checkpoint kinase 2 . The former protein is responsible for modulating the formation of the spindle and karyotheca during mitosis, while the latter is known to inhibit the cell cycle [33,34]. From the expression of two transcripts it would be more logic to predict that $\alpha$-TTP might be involved in blocking the cell cycle process. This prediction is supported by the fact that we also detected a 1.54-fold decrease in the nucleolar and coiled-body phosphoprotein 1 and a 1.73-fold decrease in the eukaryotic translation initiation factor 5A mRNA; these genes play important roles in the regulation of transcription and translation, respectively [35,36]. At the same time, we also detected increased expression of a number of pro-apoptotic genes in cells expressing the human $\alpha$-TTP eukaryotic expression vector. For example BCL-2 modifying factor, a pro-apoptotic protein found important in cell death signaling pathway [37], was upregulated 1.55-fold. Caspase 7, an executioner protein in cell apoptosis [38] also showed a 1.52-fold change in expression. This finding is in accordance with that of a previous study, in which $\alpha$-TTP-null mice liver was used; the authors of that report found that numerous genes related to the promotion of cell proliferation and the inhibition 
of apoptosis were markedly upregulated [39]. These effects, i.e., cell cycle inhibition and cell apoptosis promotion suggested that $\alpha$-TTP might have anti-cancer function. Vitamin E has previously been shown to be effective in the treatment of certain cancers [40-42]. However, it is also possible that $\alpha$-TTP acts synergistically together with its ligand in the regulation of cell cycle and apoptosis.

According to the present results, the expression of some genes related to cell signaling and gene regulation also changed significantly compared to the control group. For example, Hypoxia-inducible factor 1 (HIF-1) was sensitive to stress signals caused by hypoxia [43]. It was previously reported that transcription of the $\alpha$-TTP gene in human hepatocytes increased in response to hypoxia treatment [44]. On the contrary, exposure to hyperoxia for $48 \mathrm{~h}$ led to a decrease in the expression of $\alpha$-TTP mRNA in rat liver, while the level of TBARS increased significantly [45]. Our results also showed that HIF-1 was upregulated by 1.71-fold in the human $\alpha$-TTP eukaryotic expression vector group, which implied that $\alpha$-TTP could react to oxidative stress. It was suggested that the increased $\alpha$-TTP expression in response to hypoxia-induced oxidative stress might have triggered the formation of additional carriers to transport vitamin E, and consequently reduced further damage [44]. In addition, Interferon regulatory factor 7 , an important signaling molecule that induces interferon formation, which is able to activate the apoptosis pathway and remove inflammatory cells [46], was also upregulated 1.84-fold. We also found a few downregulated transcripts such as Protein arginine methyltransferase and CD3e molecule, epsilon associated protein, which has never been reported before. Further studies are needed to understand these findings.

Qian [9] demonstrated that $\alpha$-tocopherol was located in lysosomes together with $\alpha$-TTP after entering hepatocytes. However, the mechanism by which $\alpha$-TTP is transferred to the cell surface together with $\alpha$-tocopherol remains unknown. It is probably that additional factors are also required in this process [26]. Therefore, we have been devoted to searching for some potential elements which contribute to the transfer process. Kono [7] reviewed that phosphoinositide was a kind of possible factor critical for intracellular transport of $\alpha$-tocopherol, as $\alpha$-TTP could interact preferentially with phosphatidylinositol 4, 5-bisphosphate in transferring process. PI(4)P is produced by PI-4-kinase in the trans-Golgi. One report showed that $\mathrm{PI}(4) \mathrm{P}$ would back-transfer from the trans-Golgi to the endoplasmic reticulum (ER) during oxysterol-binding protein (OSBP) transport, which was another family of lipid transfer protein, just like $\alpha$-TTP [47]. Moreover, some lipoproteins which would be secreted outside the membrane to transfer $\alpha$-tocopherol in serum were processed through ER-Golgi pathway simultaneously with $\alpha$-tocopherol transport by $\alpha$-TTP. We hence speculated that ER-Golgi pathway became more active in the course of transport. In the present study, several genes involved in cellular movement were significantly affected in response to $\alpha$-TTP expression, including SEC23A (1.51-fold increase), RTP4 (3.13-fold increase), CLIC3 (1.57-fold increase), CENPE (1.72-fold increase), KCNQ1 (1.53-fold increase), GOLGA4 (1.70-fold increase), BNIP3 (1.55-fold increase) and CENPF (1.54-fold increase). SEC23A was once reported as an essential component of vesicles that transport secretory proteins from the ER to the Golgi. A SEC23A mutation would lead to abnormal ER to Golgi trafficking [48]. GOLGA4, also referred to as Trans-Golgi p230, which located in the Golgi apparatus, might play a role in delivery of transport vesicles from the trans-Golgi to plasma membrane [49]. Based on the information in cBioPortal for Cancer Genomics database, the Spearman's Correlations are 0.48 and 0.52, respectively, in mRNA co-expression: Tocopherol Transfer Protein A (TTPA) vs. GOLGA4 and TTPA vs. SEC24A in Liver Hepatocellular Carcinoma (Figure 3) [50]. It is speculated that these two factors were regulated when $\alpha$-tocopherol transported by $\alpha$-TTP, then activated ER-Golgi pathway, finally promoted the transferring process. Besides, other factors were also involved in different transport processes, and some of them were found to be the components of endoplasmic reticulum [51-53]. Further validation to these genes by quantitative real-time PCR was conducted, results showed that expression of RTP4, CENPE and BNIP3 were significantly higher than in the control group, and GOLGA4 expression also showed more than two times increase than control; this indicates these genes may play pivotal roles in the transferring process. Research investigating this possibility will soon be conducted. 


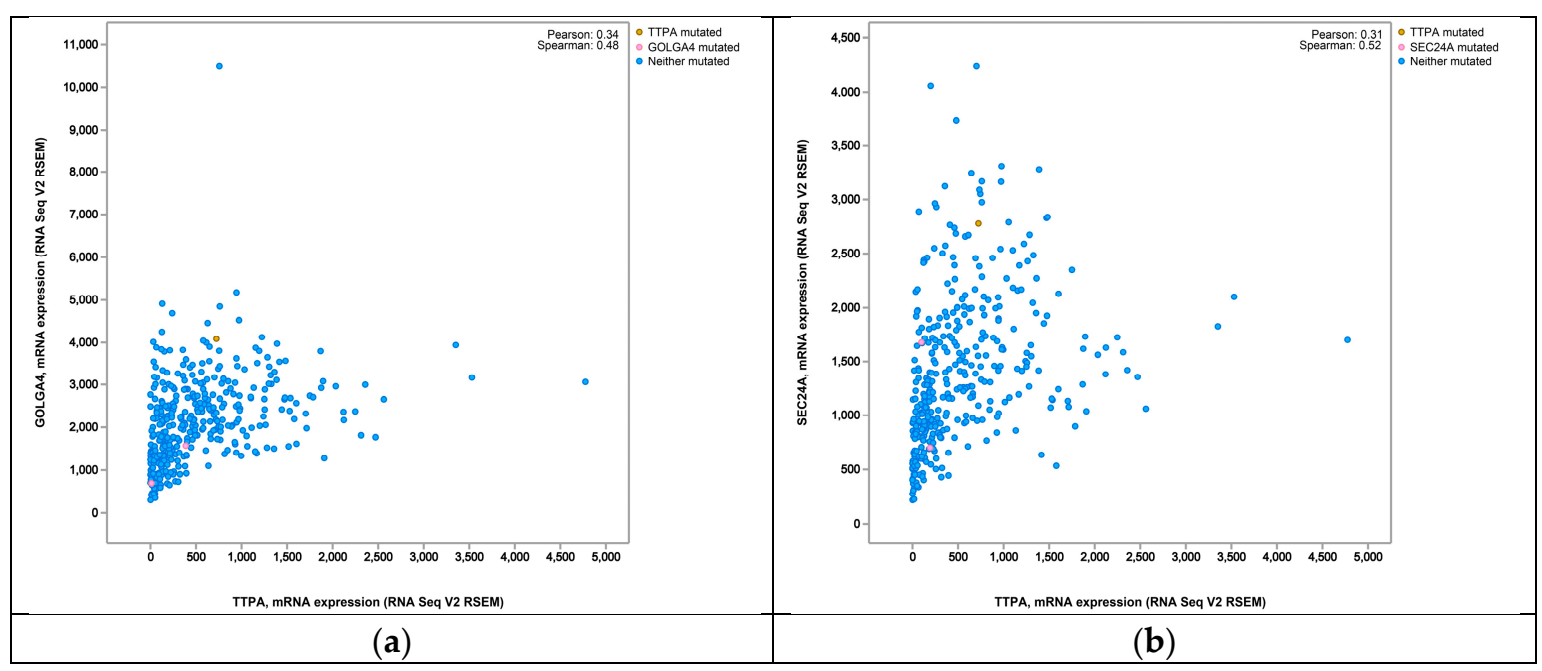

Figure 3. mRNA co-expression in Liver Hepatocellular Carcinoma: (a) Tocopherol Transfer Protein A (TTPA) vs. Golgin subfamily a 4 (GOLGA4); (b) TTPA vs. Sec24 homolog A (SEC24 A).

\section{Materials and Methods}

\subsection{Construction of a Human Eukaryotic Expression Vector}

First, human $\alpha$-TTP (GenBank: NM_000370) CDS area gene sequences were synthesized artificially, and Kpn I and Xba I enzyme cutting sites were added in the 5'and 3' end, respectively. This was used for cloning to the eukaryotic expression vector. The gene sequences were synthesized by Takara Biotechnology (Dalian, China) Co., Ltd.

The human $\alpha$-TTP eukaryotic expression vector was then constructed. Enzyme digestion reaction was applied to the pcDNA 3.1-mycHisa with Kpn I and Xba I endonucleases. The components were gently mixed and centrifuged, this was followed by incubation in a $37^{\circ} \mathrm{C}$ water bath for $1 \mathrm{~h}$. The composition of the enzyme digestion reaction is given in Table 2.

Table 2. Composition of the enzyme digestion reaction.

\begin{tabular}{cc}
\hline Ingredients & Volume \\
\hline DNA & $\leqslant 1 \mu \mathrm{g}$ \\
Kpn I & $1 \mu \mathrm{L}$ \\
Xba I & $1 \mu \mathrm{L}$ \\
Buffer & $5 \mu \mathrm{L}$ \\
$\mathrm{ddH}_{2} \mathrm{O}$ & $\mathrm{X} \mu \mathrm{L}$ \\
Total & $50 \mu \mathrm{L}$ \\
\hline
\end{tabular}

Carrier segments were extracted by agarose gel electrophoresis after enzyme digestion; the extraction reaction was conducted by means of a gel extraction kit (Omega Bio-tek; Norcross, GA, USA). T4 ligases were then used to ligate the human $\alpha$-TTP CDS area gene sequences and the pcDNA 3.1-mycHisa from the extraction. For ligation the reaction mix was incubated overnight at $16^{\circ} \mathrm{C}$ and products were then inserted into Escherichia coli followed by extraction of the plasmid from positive colonies. The composition of the ligation reaction is shown in Table 3. 
Table 3. Composition of the ligation reaction.

\begin{tabular}{cc}
\hline Ingredients & Volume \\
\hline Vector DNA & $5 \mu \mathrm{L}$ \\
$\alpha$-TTP DNA & $3 \mu \mathrm{L}$ \\
Buffer & $1 \mu \mathrm{L}$ \\
T4 ligase & $1 \mu \mathrm{L}$ \\
Total & $10 \mu \mathrm{L}$ \\
\hline
\end{tabular}

Single colonies were picked and transferred into $1 \mathrm{~mL}$ liquid Luria-Bertani (LB) medium; shaking incubation was conducted for $12 \mathrm{~h}$ at $37^{\circ} \mathrm{C}$. A PCR reaction was applied to screen positive colonies using the upstream primer 5'-CGCCAGGGTTTTCCCAGTCACGAC-3' and downstream primer 5'-GAGCGGATAACAATTTCACACAGG-3'. Subsequently, plasmid DNA was extracted by the alkaline lysis method, and was sequenced with the universal primer T7 in Beijing AuGCT DNA-SYN Biotechnology Co., Ltd. (Beijing, China).

\subsection{Expression of Human $\alpha$-TTP Eukaryotic Expression Vector in HepG2 Cells}

Plasmid DNA was transfected into HepG2 cells. The HepG2 cell line was obtained from the lab of Dr. and Professor Wei-quan Liu (China Agricultural University, Beijing, China). First, normal HepG2 cells were picked up and cultured in 6-well plates. An inverted microscope was used to inspect cells before transfection. The culture medium was removed when the cells reached $90 \%$ confluency. The cells were washed twice with DMEM medium and the medium was then removed completely. In two, 1.5-mL centrifuge tubes the following solutions were prepared: in the first tube $4 \mu \mathrm{g}$ plasmid DNA was mixed with $250 \mu \mathrm{L}$ Opti-MEN ${ }^{\circledR}$ I Reduced Serum Medium (Invitrogen, Carlsbad, CA, USA), while, in the second tube, $10 \mu \mathrm{L}$ Lipofectamine ${ }^{\circledR} 2000$ was mixed with $250 \mu \mathrm{L}$ Opti-MEN ${ }^{\circledR}$ I Reduced Serum Medium (Invitrogen). The content of the tubes were mixed, the mixture was left for $30 \mathrm{~min}$ and dropped onto the cells and the cells were cultured in an environment of $5 \% \mathrm{CO}_{2}$, at $37^{\circ} \mathrm{C}$ for 4-6 h. The liquid was then discarded and the cells were washed with DMEM medium an additional two times. The cells were then cultured in DMEM medium without double resistant containing $10 \%$ fetal bovine serum (FBS) in an environment of $5 \% \mathrm{CO}_{2}$, at $37^{\circ} \mathrm{C}$. A blank control group and an empty vector transfection control group were designed simultaneously.

The human $\alpha$-TTP eukaryotic expression vector was examined in HepG2 cells with quantitative real-time PCR, western blotting and immunofluorescence. Total RNA was extracted from all groups after $36 \mathrm{~h}$ of culture. The primers used for PCR were designed with Primer 5.0, based on human $\alpha$-TTP sequences (GenBank accession number: NM_000370) and $\beta$-actin gene sequences (GenBank: NM_001101). Details of primers for qRT-PCR are given in Table 4.

Table 4. Details of primers used for quantitative real-time PCR.

\begin{tabular}{ccc}
\hline Name of Genes & Primer Sequence & Product Size (bp) \\
\hline$\alpha$-TTP & $\begin{array}{c}\text { F: ACAGGAGGTAGAAACTCAGCG } \\
\text { R: TCTTCTTGGCTACGGATGGA }\end{array}$ & 104 \\
\hline$\beta$-actin & $\begin{array}{c}\text { F: CTCACCGAGCGCGGCTACAG } \\
\text { R: GGAGCTGGAAGCAGCCGTGG }\end{array}$ & 126 \\
\hline
\end{tabular}

Total proteins from all groups were extracted after $48 \mathrm{~h}$ of culture, and $\alpha$-TTP protein expression was determined by western-blotting. The primary antibody was human $\alpha$-TTP monoclonal (Abnova, Taiwan, Dilution ratio 1:1000) and the secondary antibody was goat anti-mouse (Dilution ratio 1:5000) (from Beijing B \& M Biotech Co., Ltd., Beijing, China).

Immunofluorescence was also used to examine expression of $\alpha$-TTP after $48 \mathrm{~h}$ of culture. First, the culture medium was discarded. The cells were washed with cold $\left(4{ }^{\circ} \mathrm{C}\right)$ PBS 3 times and 
$500 \mu \mathrm{L}$ fixative (propyl alcohol:methyl alcohol, 3:1) was added to each well of a 6-well plate, at $4{ }^{\circ} \mathrm{C}$. The fixative was discarded after $10 \mathrm{~min}$ and the cells were washed again with phosphate buffer saline (PBS) 3 times. The primary antibody (monoclonal antibody of human $\alpha$-TTP, Abnova, Taiwan, 1:100 dilution) was diluted with PBS and $500 \mu \mathrm{L}$ of the solution was added to each well. The cells were then incubated for $1 \mathrm{~h}$ in the dark and washed 3 times with PBS. This was followed by the addition of $500 \mu \mathrm{L}$ of the secondary antibody (goat-anti-mouse, FITC conjugated; from Beijing Solarbio Technology Co., Ltd., Beijing, China; 1:100 dilution with PBS) to each well. The cells were again incubated for $1 \mathrm{~h}$ under in the dark. Finally, they were washed 3 times with PBS and examined using a fluorescence microscope (Olympus, Tokyo, Japan).

\subsection{RNA Extraction, Microarray Analysis and Statistics}

Total RNA from HepG2 cells containing an empty pcDNA3.1-mycHisa vector (control group) and those with a human $\alpha$-TTP eukaryotic expression vector (treatment group) was extracted and processed for microarray analysis. Genes whose expression changes exceeded 1.5-fold were used for gene ontology (GO) annotation and Pathway analysis to characterize their biological properties.

\section{Conclusions}

In conclusion, our results demonstrate that $\alpha$-TTP is involved in various physiological processes. Expression of the protein resulted in many differentially expressed transcripts and certain effects were similar to those caused by vitamin E. Moreover, some novel factors were also identified which might have relevance to the transport process of the $\alpha$-TTP/vitamin E complex, and qRT-PCR was applied to verify their expression. It is possible that some of them may contribute to the transferring process. Nevertheless, further research is still needed to verify it in detail.

Acknowledgments: Many thanks are due to Wei-quan Liu for his supervision of the experiments and to Zoltan Machaty (Purdue University, West Lafayette, IN, USA) for his comments on the manuscript. The present study was supported by projects of the National Natural Science Foundation of China (No. 31172230 and No. 31472119).

Author Contributions: Hai-Ling Luo, Jun-Cai Fu and Kun Liu conceived and designed the experiments; Kun Liu, Zhao-Yun Zuo, Hui-Na Jia and Yang-Hua Qu performed the experiments; Yang-Hua Qu, Kun Liu, Yong Ma analyzed the data; Hailing Luo contributed reagents/materials/analysis tools; Yang-Hua Qu wrote the paper.

Conflicts of Interest: The authors declare no conflict of interest.

\section{Abbreviations}

$\begin{array}{ll}\alpha \text {-TTP } & \alpha \text {-tocopherol transfer protein } \\ \text { qRT-PCR } & \text { quantitative real-time polymerase chain reaction } \\ \text { SEC23A } & \text { sec23 homolog A } \\ \text { RTP4 } & \text { receptor transporter protein } 4 \\ \text { CLIC3 } & \text { chloride intracellular channel } 3 \\ \text { CENPE } & \text { centromere protein E } \\ \text { KCNQ1 } & \text { potassium voltage-gated channel, KQT-like subfamily } \\ \text { GOLGA4 } & \text { golgi autoantigen, golgin subfamily a, } 4 \\ \text { BNIP3 } & \text { bcl2/adenovirus E1B 19 kDa interacting protein } 3 \\ \text { CENPF } & \text { centormere protein F, 350/400 ka (mitosin) }\end{array}$

\section{References}

1. Evans, H.M.; Bishop, K.S. On the existence of a hitherto unrecognized dietary factor essential for reproduction. Science 1922, 56, 650-651. [CrossRef] [PubMed]

2. Burton, G.W.; Joyce, A.; Ingold, K.U. Is vitamin E the only lipid-soluble, chain-breaking antioxidant in human blood plasma and erythrocyte membranes? Arch. Biochem. Biophys. 1983, 221, 281-290. [CrossRef]

3. Schneider, C. Chemistry and biology of vitamin E. Mol. Nutr. Food Res. 2005, 49, 7-30. [CrossRef] [PubMed]

4. Zingg, J.M. Modulation of signal transduction by vitamin E. Mol. Asp. Med. 2007, 28, 481-506. [CrossRef] [PubMed] 
5. Azzi, A.; Gysin, R.; Kempna, P.; Munteanu, A.; Negis, Y.; Villacorta, L.; Visarius, T.; Zingg, J.M. Vitamin E mediates cell signaling and regulation of gene expression. Ann. N. Y. Acad. Sci. 2004, 1031, 86-95. [CrossRef] [PubMed]

6. Azzi, A. Molecular mechanism of $\alpha$-tocopherol action. Free Radic. Biol. Med. 2007, 43, 16-21. [CrossRef] [PubMed]

7. Kono, N.; Arai, H. Intracellular transport of fat-soluble vitamins A and E. Traffic 2015, 16, 19-34. [CrossRef] [PubMed]

8. Catignani, G.L. An $\alpha$-tocopherol binding protein in rat liver cytoplasm. Biochem. Biophys. Res. Commun. 1975, 67, 66-72. [CrossRef]

9. Qian, J.; Morley, S.; Wilson, K.; Nava, P.; Atkinson, J.; Manor, D. Intracellular trafficking of vitamin E in hepatocytes: The role of tocopherol transfer protein. J. Lipid Res. 2005, 46, 2072-2082. [CrossRef] [PubMed]

10. Sato, Y.; Hagiwara, K.; Arai, H.; Inoue, K. Purification and characterization of the $\alpha$-tocopherol transfer protein from rat liver. FEBS Lett. 1991, 288, 41-45. [CrossRef]

11. Arita, M.; Sato, Y.; Miyata, A.; Tanabe, T.; Takahashi, E.; Kayden, H.J.; Arai, H.; Inoue, K. Human $\alpha$-tocopherol transfer protein: cDNA cloning, expression and chromosomal localization. Biochem. J. 1995, 306, 437-443. [CrossRef] [PubMed]

12. Sato, Y.; Arai, H.; Miyata, A.; Tokita, S.; Yamamoto, K.; Tanabe, T.; Inoue, K. Primary structure of $\alpha$-tocopherol transfer protein from rat liver. Homology with cellular retinaldehyde-binding protein. J. Biol. Chem. 1993, 268, 17705-17710. [PubMed]

13. Ouahchi, K.; Arita, M.; Kayden, H.; Hentati, F.; Ben, H.M.; Sokol, R.; Arai, H.; Inoue, K.; Mandel, J.L.; Koenig, M. Ataxia with isolated vitamin E deficiency is caused by mutations in the $\alpha$-tocopherol transfer protein. Nat. Genet. 1995, 9, 141-145. [CrossRef] [PubMed]

14. Jishage, K.; Arita, M.; Igarashi, K.; Iwata, T.; Watanabe, M.; Ogawa, M.; Ueda, O.; Kamada, N.; Inoue, K.; Arai, H.; et al. A-tocopherol transfer protein is important for the normal development of placental labyrinthine trophoblasts in mice. J. Biol. Chem. 2001, 276, 1669-1672. [CrossRef] [PubMed]

15. Kim, H.S.; Arai, H.; Arita, M.; Sato, Y.; Ogihara, T.; Inoue, K.; Mino, M.; Tamai, H. Effect of $\alpha$-tocopherol status on $\alpha$-tocopherol transfer protein expression and its messenger RNA level in rat liver. Free Radic. Res. 1998, 28, 87-92. [PubMed]

16. Shaw, H.M.; Huang, C. Liver $\alpha$-tocopherol transfer protein and its mRNA are differentially altered by dietary vitamin E deficiency and protein insufficiency in rats. J. Nutr. 1998, 128, 2348-2354. [PubMed]

17. Fechner, H.; Schlame, M.; Guthmann, F.; Stevens, P.A.; Rustow, B. $\alpha$ - and $\delta$-tocopherol induce expression of hepatic $\alpha$-tocopherol-transfer-protein mRNA. Biochem. J. 1998, 331 Pt 2, 577-581. [CrossRef] [PubMed]

18. Barella, L.; Muller, P.Y.; Schlachter, M.; Hunziker, W.; Stocklin, E.; Spitzer, V.; Meier, N.; de Pascual-Teresa, S.; Minihane, A.M.; Rimbach, G. Identification of hepatic molecular mechanisms of action of $\alpha$-tocopherol using global gene expression profile analysis in rats. Biochim. Biophys. Acta 2004, 1689, 66-74. [CrossRef] [PubMed]

19. Chen, W.H.; Li, Y.J.; Wang, M.S.; Kang, Z.C.; Huang, H.L.; Shaw, H.M. Elevation of tissue $\alpha$-tocopherol levels by conjugated linoleic acid in C57BL/6J mice is not associated with changes in vitamin E absorption or $\alpha$-carboxyethyl hydroxychroman production. Nutrition 2012, 28, 59-66. [CrossRef] [PubMed]

20. Lauridsen, C.; Theil, P.K.; Jensen, S.R.K. Composition of $\alpha$-tocopherol and fatty acids in porcine tissues after dietary supplementation with vitamin E and different fat sources. Anim. Feed Sci. Technol. 2013, 179, 93-102. [CrossRef]

21. Thakur, V.; Morley, S.; Manor, D. Hepatic $\alpha$-tocopherol transfer protein: Ligand-induced protection from proteasomal degradation. Biochemistry 2010, 49, 9339-9344. [CrossRef] [PubMed]

22. Liu, K.; Luo, H.L.; Yue, D.B.; Ge, S.Y.; Yuan, F.; Yan, L.Y.; Jia, H.N. Molecular cloning and characterization of the sheep $\alpha$-TTP gene and its expression in response to different vitamin E status. Gene 2012, 494, 225-230. [CrossRef] [PubMed]

23. Liu, K.; Luo, H.L.; Zuo, Z.Y.; Jia, H.N.; Zhang, Y.W.; Chang, Y.F.; Jiao, L.J. Regulation of sheep $\alpha$-TTP by dietary vitamin $\mathrm{E}$ and preparation of monoclonal antibody for sheep $\alpha$-TTP. Gene 2014, 540, 110-116. [CrossRef] [PubMed]

24. Liu, K.; Zuo, Z.Y.; Jia, H.N.; Luo, H.L. Screening of Ovine $\alpha$-TTP interacting proteins by using Co-immunoprecipitation coupled with Mass spectrometry. Chin. J. Anim. Sci. 2014, 50, 80-83.

25. Zuo, Z.Y.; Luo, H.L.; Liu, K.; Jia, H.N.; Zhang, Y.W.; Jiao, L.J.; Chang, Y.F. Dietary vitamin E affects $\alpha$-TTP mRNA levels in different tissues of the Tan sheep. Gene 2014, 541, 1-7. [CrossRef] [PubMed] 
26. Manor, D.; Morley, S. The $\alpha$-tocopherol transfer protein. Vitam. Horm. 2007, 76, 45-65. [PubMed]

27. Schock, B.C.; van der Vliet, A.; Corbacho, A.M.; Leonard, S.W.; Finkelstein, E.; Valacchi, G.; Obermueller-Jevic, U.; Cross, C.E.; Traber, M.G. Enhanced inflammatory responses in $\alpha$-tocopherol transfer protein null mice. Arch. Biochem. Biophys. 2004, 423, 162-169. [CrossRef] [PubMed]

28. Vasu, V.T.; Hobson, B.; Gohil, K.; Cross, C.E. Genome-wide screening of $\alpha$-tocopherol sensitive genes in heart tissue from $\alpha$-tocopherol transfer protein null mice (ATTP-/-). FEBS Lett. 2007, 581, 1572-1578. [CrossRef] [PubMed]

29. Sedy, J.; Bekiaris, V.; Ware, C.F. Tumor necrosis factor superfamily in innate immunity and inflammation. Cold Spring Harb. Perspect. Biol. 2015, 7, a016279. [CrossRef] [PubMed]

30. Eddleston, J.; Christiansen, S.C.; Zuraw, B.L. Functional expression of the C-X-C chemokine receptor CXCR4 by human bronchial epithelial cells: Regulation by proinflammatory mediators. J. Immunol. 2002, 169, 6445-6451. [CrossRef] [PubMed]

31. Fillmore, R.A.; Mitra, A.; Xi, Y.; Ju, J.; Scammell, J.; Shevde, L.A.; Samant, R.S. Nmi ( $N$-mycinteractor) inhibits wnt/ $\beta$-catenin signaling and retards tumor growth. Int. J. Cancer 2009, 125, 556-564. [CrossRef] [PubMed]

32. Gadient, R.A.; Patterson, P.H. Leukemia inhibitory factor, Interleukin 6, and other cytokines using the GP130 transducing receptor: Roles in inflammation and injury. Stem Cells 1999, 17, 127-137. [CrossRef] [PubMed]

33. Clarke, P.R.; Zhang, C. Ran GTPase: A master regulator of nuclear structure and function during the eukaryotic cell division cycle? Trends Cell Biol. 2001, 11, 366-371. [CrossRef]

34. Stolz, A.; Ertych, N.; Kienitz, A.; Vogel, C.; Schneider, V.; Fritz, B.; Jacob, R.; Dittmar, G.; Weichert, W.; Petersen, I.; et al. The CHK2-BRCA1 tumour suppressor pathway ensures chromosomal stability in human somatic cells. Nat. Cell Biol. 2010, 12, 492-499. [CrossRef] [PubMed]

35. Hwang, Y.C.; Lu, T.-Y.; Lin, C.-T.; Kao, C.-F.; Wu, H.-C.; Yeh, N.-H. NOLC1, a transcription factor, synergistically regulates MDM2 expression with TP53 to promote the progression of nasopharyngeal carcinoma. Cancer Res. 2008, 68, LB-170.

36. Park, M.H. The post-translational synthesis of a polyamine-derived amino acid, hypusine, in the eukaryotic translation initiation factor 5A (eIF5A). J. Biochem. 2006, 139, 161-169. [CrossRef] [PubMed]

37. Hubner, A.; Cavanagh-Kyros, J.; Rincon, M.; Flavell, R.A.; Davis, R.J. Functional cooperation of the proapoptotic Bcl2 family proteins Bmf and Bim in vivo. Mol. Cell. Biol. 2009, 30, 98-105. [CrossRef] [PubMed]

38. Wang, D.H.; Hu, J.R.; Wang, L.Y.; Hu, Y.J.; Tan, F.Q.; Zhou, H.; Shao, J.Z.; Yang, W.X. The apoptotic function analysis of p53, Apaf1, Caspase3 and Caspase7 during the spermatogenesis of the Chinese fire-bellied newt Cynops orientalis. PLoS ONE 2012, 7, e39920. [CrossRef] [PubMed]

39. Gohil, K.; Schock, B.C.; Chakraborty, A.A.; Terasawa, Y.; Raber, J.; Farese, R.J.; Packer, L.; Cross, C.E.; Traber, M.G. Gene expression profile of oxidant stress and neurodegeneration in transgenic mice deficient in $\alpha$-tocopherol transfer protein. Free Radic. Biol. Med. 2003, 35, 1343-1354. [CrossRef]

40. Yoshikawa, T.; Yoshida, N.; Manabe, H.; Terasawa, Y.; Takemura, T.; Kondo, M. $\alpha$-Tocopherol protects against expression of adhesion molecules on neutrophils and endothelial cells. Biofactors 1998, 7, 15-19. [CrossRef] [PubMed]

41. Gysin, R.; Azzi, A.; Visarius, T. $\gamma$-Tocopherol inhibits human cancer cell cycle progression and cell proliferation by down-regulation of cyclins. FASEB J. 2002, 16, 1952-1954. [CrossRef] [PubMed]

42. Hodul, P.J.; Dong, Y.; Husain, K.; Pimiento, J.M.; Chen, J.; Zhang, A.; Francois, R.; Pledger, W.J.; Coppola, D.; Sebti, S.M.; et al. Vitamin E $\delta$-tocotrienol induces p27KIP1-dependent cell-cycle arrest in pancreatic cancer cells via an E2F-1-dependent mechanism. PLoS ONE 2013, 8, e52526. [CrossRef] [PubMed]

43. Semenza, G.L. HIF-1: Mediator of physiological and pathophysiological responses to hypoxia. J. Appl. Physiol. 2000, 88, 1474-1480. [PubMed]

44. Ulatowski, L.; Dreussi, C.; Noy, N.; Barnholtz-Sloan, J.; Klein, E.; Manor, D. Expression of the $\alpha$-tocopherol transfer protein gene is regulated by oxidative stress and common single-nucleotide polymorphisms. Free Radic. Biol. Med. 2012, 53, 2318-2326. [CrossRef] [PubMed]

45. Ban, R.; Takitani, K.; Kim, H.S.; Murata, T.; Morinobu, T.; Ogihara, T.; Tamai, H. $\alpha$-Tocopherol transfer protein expression in rat liver exposed to hyperoxia. Free Radic. Res. 2002, 36, 933-938. [CrossRef] [PubMed]

46. Goubau, D.; Romieu-Mourez, R.; Solis, M.; Hernandez, E.; Mesplede, T.; Lin, R.; Leaman, D.; Hiscott, J. Transcriptional re-programming of primary macrophages reveals distinct apoptotic and anti-tumoral functions of IRF-3 and IRF-7. Eur. J. Immunol. 2009, 39, 527-540. [CrossRef] [PubMed] 
47. Mesmin, B.; Bigay, J.; Moser, V.F.J.; Lacas-Gervais, S.; Drin, G.; Antonny, B. A four-step cycle driven by PI(4)P hydrolysis directs sterol/PI(4)P exchange by the ER-Golgi tether OSBP. Cell 2013, 155, 830-843. [CrossRef] [PubMed]

48. Boyadjiev, S.A.; Fromme, J.C.; Ben, J.; Chong, S.S.; Nauta, C.; Hur, D.J.; Zhang, G.; Hamamoto, S.; Schekman, R.; Ravazzola, M.; et al. Cranio-lenticulo-sutural dysplasia is caused by a SEC23A mutation leading to abnormal endoplasmic-reticulum-to-Golgi trafficking. Nat. Genet. 2006, 38, 1192-1197. [CrossRef] [PubMed]

49. Erlich, R.; Gleeson, P.A.; Campbell, P.; Dietzsch, E.; Toh, B.H. Molecular characterization of trans-Golgi p230. A human peripheral membrane protein encoded by a gene on chromosome $6 \mathrm{p} 12-22$ contains extensive coiled-coil $\alpha$-helical domains and a granin motif. J. Biol. Chem. 1996, 271, 8328-8337. [PubMed]

50. cBioPortal for Cancer Genomics. Available online: http://www.cbioportal.org/ (accessed on 21 December 2015).

51. Valenzuela, S.M.; Martin, D.K.; Por, S.B.; Robbins, J.M.; Warton, K.; Bootcov, M.R.; Schofield, P.R.; Campbell, T.J.; Breit, S.N. Molecular cloning and expression of a chloride ion channel of cell nuclei. J. Biol. Chem. 1997, 272, 12575-12582. [CrossRef] [PubMed]

52. Yang, Z.Y.; Guo, J.; Li, N.; Qian, M.; Wang, S.N.; Zhu, X.L. Mitosin/CENP-F is a conserved kinetochore protein subjected to cytoplasmic dynein-mediated poleward transport. Cell Res. 2003, 13, 275-283. [CrossRef] [PubMed]

53. Andersen, M.N.; Olesen, S.P.; Rasmussen, H.B. Kv7.1 surface expression is regulated by epithelial cell polarization. Am. J. Physiol. Cell Physiol. 2011, 300, C814-C824. [CrossRef] [PubMed]

(C) 2016 by the authors; licensee MDPI, Basel, Switzerland. This article is an open access article distributed under the terms and conditions of the Creative Commons Attribution (CC-BY) license (http:/ / creativecommons.org/licenses/by/4.0/). 